\title{
Oral lichenoid reaction due to nickel alloy contact hypersensitivity
}

\author{
Kaushal Mahendra Shah, ${ }^{1}$ Manish Rameshchand Agrawal, ${ }^{2}$ \\ Suraj Appasaheb Chougule, ${ }^{3}$ Jagruti Dalpatram Mistry ${ }^{4}$
}

${ }^{1}$ Department of Oral Medicine, Diagnosis and Radiology, Bharati Vidyapeeth Deemed University Dental College, Sangli, Maharashtra, India ${ }^{2}$ Department of Prosthodontics, Bharati Vidyapeeth Deemed University Dental College, Sangli, Maharashtra, India ${ }^{3}$ Department of Periodontology, Bharati Vidyapeeth Deemed University Dental College, Sangli, Maharashtra, India

${ }^{4}$ Department of Oral and Maxillofacial Surgery, Yogita Dental College and Hospital Khed, Maharashtra, India

Correspondence to Dr Kaushal Mahendra Shah, thirty2creations@gmail.com
To cite: Shah KM, Agrawal MR, Chougule SA, et al. BMJ Case Rep Published online: [please include Day Month Year] doi:10.1136/bcr-2013009754

\section{DESCRIPTION}

A middle aged patient came to our dental out patients department with a complaint of burning sensation in right buccal mucosa and right side of tongue and an inability to eat spicy foods since a few months. Medical and family histories were non-contributory. The patient was not on any longterm medication either. However, the patient gave a dental history of fabrication of metal bridge for missing mandibular right molar a few years back. Intraoral examination revealed a three-unit white metal bridge involving the right mandibular second premolar and first and second molars. The buccal mucosa adjacent to the bridge showed a white keratotic reticular and plaque-like patch with central ruptured bullae with an erythematous halo (figure 1). The right side of the tongue in contact with the bridge also showed a reticular whitish lesion with some depapillation of the dorsum. The rest of the oral mucosa appeared normal. The unilateral lesions looked like oral lichen planus (OLP). However, based on the history and clinical findings, we suspected the lesions to be due to contact allergy to nickel chromium. A positive patch test for nickel allergen confirmed the same, and these lesions were diagnosed as oral lichenoid reaction (OLR), a name

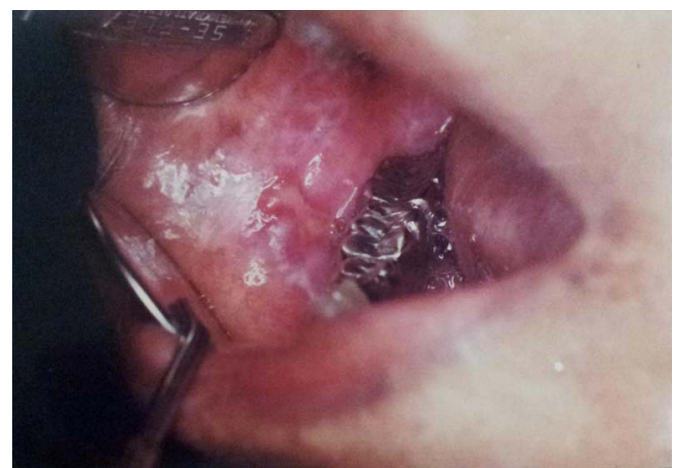

Figure 1 Intraoral photograph. Showing lichen planus like appearance of right buccal mucosa adjacent to the metal bridge. derived for having an appearance clinically and histologically similar to OLP. ${ }^{1}$

OLR can be induced by the intake of drugs, hypersensitivity to dental restorative metals, ${ }^{2} 3$ acrylates, flavourings and other substances. In our case, it was due to hypersensitivity to nickel. The treatment included the replacement of the white metal bridge by a metal-free ceramic one. The resolution of lesions is expected within few weeks to months.

\section{Learning points}

- A good history, clinical evaluation and biopsy are a must to help differentiate oral lichenoid reaction (OLR) from other inflammatory, reactive, cell-mediated lesions seen on oral mucosa.

- Oral lichen planus (OLP) and OLR look identical clinically and histologically; however, a simple replacement of causative drug or allergic agent will resolve the OLR lesions, while OLP would require more long-term monitoring considering its potentially malignant nature and need for specific treatment, directed towards the immunological origin.

Competing interests None.

Patient consent Obtained.

Provenance and peer review Not commissioned; externally peer reviewed.

\section{REFERENCES}

1 Ismail SB, Kumar SKS, Zain RB. Oral lichen planus and lichenoid reactions: etiopathogenesis, diagnosis, management and malignant transformation. J Oral Sci 2007:49:89-106.

2 Koch P, Bahmer FA. Oral lesions and symptoms related to metals used in dental restorations: a clinical, allergological, and histologic study. J Am Acad Dermatol 1999;41:422-30.

3 Skoglund $A$, Egelrud T. Hypersensitivity reactions to dental materials in patients with lichenoid oral mucosal lesions and in patients with burning mouth syndrome. Scand I Dent Res 1991;99:320-8. 


\section{Images in...}

Copyright 2013 BMJ Publishing Group. All rights reserved. For permission to reuse any of this content visit http://group.bmj.com/group/rights-licensing/permissions.

BMJ Case Report Fellows may re-use this article for personal use and teaching without any further permission.

Become a Fellow of BMJ Case Reports today and you can:

- Submit as many cases as you like

- Enjoy fast sympathetic peer review and rapid publication of accepted articles

- Access all the published articles

- Re-use any of the published material for personal use and teaching without further permission

For information on Institutional Fellowships contact consortiasales@bmjgroup.com

Visit casereports.bmj.com for more articles like this and to become a Fellow 